NOTICE: this is the author's version of a work that was accepted for publication in International J ournal of Project Management. Changes resulting from the publishing process, such as peer review, editing, corrections, structural formatting, and other quality control mechanisms may not be reflected in this document. Changes may have been made to this work since it was submitted for publication. A definitive version was subsequently published in International Journal of Project Management, [VOL 31, ISSUE 6, (2013)] DOI: 10.1016/j.ijproman.2012.09.002"

\title{
Obsessive passion, competence, and performance in a project management context
}

\begin{abstract}
Obsessive passion is when people have a strong inclination toward an activity that they like, find important, and in which they spend significant time, but also feel internal pressure to engage in. Prior research has demonstrated that obsessive passion typically brings several negative consequences. The present study nuances the picture by showing that there are indeed conditions when obsessive passion can be beneficial and that it has an important role for project management. It develops and tests hypotheses on the role of project leaders’ obsessive passion for project goals. Results support that challenging goals are attained to a greater extent if the project leader scores high on obsessive passion. Such obsessive passion, in turn, is a result of the project leader’s competence (positive relationship) and the team's competence (inverted Ushaped relationship). These results have important implications for theory and future research on passion, goal theory, and competence in projects.
\end{abstract}

Keywords: Obsessive passion; Competence; Goal attainment; Goal theory; Project management 


\section{Introduction}

Practice suggests several examples in which being a competent individual or team does not ensure that challenging goals are reached. Scholars have thus debated whether and how competence contributes to attaining goals. Although the literature has established that competence is often essential to distinguish poor from exceptional performance (Aubry and Lièvre, 2010; Gillard and Price, 2005), numerous examples attest that very competent people have not reached goals that could be considered challenging. For example, the project management literature has highlighted that recruiting highly competent project leaders and project team members does not guarantee success and that such recruitments may sometimes be disappointing (e.g., Green and Compton, 2007; Lampel, 2001; McComb, Müller and Turner, 2010; Jha and Iyer, 2007). Moreover, the project management literature has highlighted that teams that are objectively deemed less competent may sometimes outperform more competent teams (Melkonian and Picq, 2010). Although no foundation exists to argue that competence does

not, indeed, contribute to attaining goals, a growing body of research examines how the relationship between competence and goal attainment may be more complex than previously theorized. Furthermore, previous studies have overlooked that competence does not simply turn into goal attainment with some kind of intervention (Dweck, 1992; Moores and Chang, 2009). Instead, several empirical studies have shown that project leaders need substantial motivation to turn competence into attaining project goals (Baum et al., 2001; Ferla et al., 2010). Although these studies have not suggested a clear motivational construct that could capture such strong motivation, and hence have not examined such relationships, they identified that a motivational force, which provides a sense of enjoyment may be needed to leverage competence for a team to attain its goals. 
With the present study, we introduce and acknowledge the strong motivation embodied in the obsessive passion construct (e.g., Bonneville-Roussy et al., 2011; Philippe et al., 2010; Vallerand et al., 2003). We also test the relevance of obsessive passion for capturing the oftenargued necessary motivation of project leaders. The social psychology research on obsessive passion—defined as an uncontrollable urge to take part in an activity—has concentrated on how the experience of obsessive passion impacts the way people behave in goal processes (Vallerand et al., 2008). The relationships among competence, obsessive passion, and goal attainment have not been tested directly, yet advancements in this stream of research and the general arguments of goal-setting-theory (Locke and Latham, 2002, 2006) lead us to suspect that obsessive passion may be one of the factors that play a key role in the relationship between competence and attaining goals. By conceptually developing and empirically testing hypotheses regarding the unexamined positive side of obsessive passion that may transfer competence to attaining goals in projects, this research provides preliminary answers to the following questions: Why is competence not positively linked to the attaining of project goals in some situations? Why can project teams with lower levels of experience sometimes reach challenging goals more effectively than teams with higher levels of competence? What is the value of project team competence in the absence of a highly motivated project leader?

Using multi-source longitudinal data from 134 large European Union projects, we test a set of hypotheses to produce plausible answers to these questions. Specifically, we first explain how both the project leader's competence and the team members' competence influence how much obsessive passion the project leader experiences. Here we suggest that the relationship is positive, but is characterized by diminishing returns, meaning that at a certain point the competence may create conditions for reduced obsessive passion in the project leader. This is consistent with commonly argued "experience effects," suggesting that too much competence 
may reduce motivation (Peterson, 2007; Williams and Stephen, 1993). Our tests show that there are no direct effects of competence on attaining goals, but instead support the argument that obsessive passion is important for mediating the competence effects on attaining goals, especially when goals are challenging. Figure 1 illustrates the hypothesized framework of the relationships this research examines. As shown, we elaborate on a mediated moderation framework in which we posit that obsessive passion plays a central role in facilitating goal attainment in projects with particularly challenging goals.

\section{--- INSERT FIGURE 1 ABOUT HERE---}

\section{Theory and hypotheses}

\subsection{Theoretical background}

To build our theoretical framework we draw from several lines of research such as project management, goal-setting theory, individual versus team competence, and passion. Competence is the underlying attributes of individuals, in terms of the diverse knowledge, skills or abilities they possess (Boyatzis, 1982). This suggests that a competent professional is qualified, capable, and able to understand and do certain things in an appropriate and effective way (Kaslow, 2004, p. 775; Rodolfa et al., 2005, p. 348). Regarding team competence, it is a system of abilities or skills that enables the team to complete familiar or new working tasks (Kauffeld, 2006).

Typically, individual competence and team competence have been linked to rather different behaviors and outcomes. Individual competence can be proven based on one’s performance output and effectiveness when acquired skills, knowledge, abilities, experience, and values are put into action (Boyatzis, 1982; Rodolfa et al., 2005; Österlund, 1997). Furthermore, studies on individual competence have centered on individuals' skills and abilities and how they assist the team with behaviors and outcomes such as creativity, intrinsic motivation, initiative, 
and identity reflection (e.g., Boyatzis, 1982; Coatsworth and Conroy, 2009; de Korwin et al., 2002; Partington et al., 2005; Rodolfa et al., 2005; Sansone, 1986; Spencer and Spencer, 1993; Vallerand and Reid, 1984). On the team level, studies have reported the effects of team competence on seizing growth opportunities (Kor, 2003), delegating specific tasks (Zhang et al., 2009), and performance on new products or projects (Haon et al., 2009, Jha and Iyer, 2007; Melkonian and Picq, 2010).

In the competence literature, studies have agreed on the ultimately positive influence of competence on performance, although such studies still call for more complex frameworks. Locke and Latham (2002, 2006), for example, noticed that on a general level, the competence construct per se is likely only part of the reason that competence can positively influence performance and attaining goals. Rather, studies have suggested that motivational elements play an important role in transforming competence into attaining goals and top performance. Studies have indicated that motivational aspects such as interest level, self-determination, feedback seeking, and intrinsic drive will increase the chances of positive goal outcomes based on competence levels (Elliot et al., 2000; Renn and Fedor, 2001; Sansone, 1986; Österlund, 1997).

Passion, which is defined as a strong inclination toward an activity that the individual likes and values; one in which the individual invests time and energy; and one that contributes to defining an individual (Vallerand et al., 2003), is a concept that has not been integrated into competence-goal attainment studies. Importantly, obsessive passion-the central construct of the present study —is stronger and more "uncontrollable” compared to milder passion (what has been denoted harmonious passion, see Vallerand et al., 2003) that develops under circumstances when time and energy are devoted freely to an activity (Deci and Ryan, 2000). This implies that obsessive passion captures something stronger than merely pursuing an activity by choice (Vallerand et al., 2003). Although obsessive passion may be associated with interpersonal 
conflict (Stenseng et al., 2011), work-home tension (Vallerand et al., 2010), and reduced quality of interpersonal relationships outside work (Philippe et al., 2010), it undoubtedly has a strong motivational component. As such, we believe that obsessive passion could assist teams in attaining goals. Unfortunately, the personal costs may be significant (see e.g., Amiot et al., 2006; Bonneville-Roussy et al., 2011).

Noteworthy is that extant goal-setting theory arguments (e.g., Locke and Latham, 2002) uphold the value of extreme focus to a point that it can be characterized as obsessive. The main arguments that emerges can be traced to Locke and Bryan's (1966) proposition that individuals who have been assigned specific goals have more pronounced performance effects compared to individuals who are assigned “do your best” goals. Because specific goals are typically characterized by higher focus and efforts, subsequent empirical studies have identified how focusing on specific and difficult goals produces the highest levels of performance (Latham and Locke, 1975, 2006; Locke, 1966; Locke and Bryan, 1966, 1967; Locke and Latham, 2002, 2006; Locke et al., 1981). Further, other empirical studies report that setting goals provides individuals with a direction, affects the individuals’ persistence, and has an energizing response (Locke, et al., 1981; Locke and Latham, 2002). Importantly, research has demonstrated that when individuals are committed to achievable goals, see the goals as important and receive constant feedback, the goal-performance relationship is strongest (Locke and Bryan; 1966, Locke, et al., 1981; Locke and Latham, 2002, 2006). Subsequently, goal-setting theory presents the possibility that constructs such as obsessive passion are related to positive outcomes in goal attainment processes, especially those that involve striving to fulfill challenging goals.

\subsection{Hypothesis development}

\subsubsection{Competence and obsessive passion}


Whereas a few studies have inquired the field of passion in a work context (e.g., Forest, Mageau, Sarrazin, and Morin, 2011), the relationship between competence and obsessive passion has not been examined previously. Research on competence and research on passion have, however, suggested we can expect a complex and ambiguous relationship between these concepts. Research has shown that individuals with low levels of competence foster a climate of anxiety, distress, frustration, or apathy. Such emotions are likely to inhibit the experience of obsessive passion (Schüler et al., 2010). Likewise, studies have shown that highly experienced and competent individuals tend to be less motivated to perform well and engage when they are more competent than the activity requires, leading to difficulties in maintaining concentration and possibly exhaustion (Moores and Chang, 2009; Vancouver and Kendall, 2006; Vancouver et al. , 2002; William and Stephen, 1993). At some point, competence may thus undermine the obsessive passion an individual has for a given activity. In the present study, we expand on these contrasting mechanisms and argue for an inverted curvilinear relationship between competence and obsessive passion.

Because low competence is associated with anxiety and apathy, it may restrict the leaders' propensity to develop obsessive passion for the project. Likewise, because people with low competence are unable to exhibit the expected level of knowledge, skills, or attitudes to complete an activity, their joy and passion will likely not develop (Kaslow et al., 2007; Vallerand et al., 2007; Vallerand et al., 2008). Instead, they risk experiencing chronic interpersonal stressors and strains that result from work overload, role ambiguity, or role conflict when carrying out the activity (Best et al., 2005; Maslach et al., 2001). This turns into a negative pattern in which the lack of achievement and productivity may impair interest for and involvement in the activity (Caldwell et al., 1992; Lampel, 2001; Maslach et al., 2001). Thus, we expect that leaders with low competence will experience less obsessive passion for the given activity. When project 
leaders feel that they do not have the necessary abilities to manage a team for project success, they may feel they are in the wrong position and consider other options rather than feeling joy in investing their time and energy into the project.

And yet, when project leaders have high competence, this too may restrict their obsessive passion because of a mismatch between their skills and what the leadership role demands. This creates a state of boredom (Csikszentmihalyi and LeFevre, 1989; Payne et al., 2011; Shernoff et al., 2003). Specifically, individuals who have worked in similar projects and can effectively manage the uncertainty, ambiguity and complexity of these project tasks (Bacarini, 1996; Song et al., 2007; Söderlund, 2004) may find the situation less demanding. Indeed, when the task complexity is too low for the individual, a reduced interest for the activity results (Mikulas and Vodanovich, 1993). Rather than developing passion (Vallerand et al., 2003), the individual can carry out the activity with little thought, effort, and attention (Csikszentmihalyi and Csikszentmihalyi, 1988; Geiwitz, 1966; Mathwick and Rigdon, 2004; Nakamura and Csikszentmihlyi, 2002). As such, when project leaders are overly competent, they may relax and thus not develop obsessive passion for the project.

The mechanisms discussed above suggest that project leaders with intermediate levels of competence may be those who develop the highest levels of obsessive passion for their project. In many ways, their competence fits the demands associated with managing the project; that is, those with medium competence are more motivated to engage in the activity because they enjoy feeling challenged, but are not extended to the point of anxiety (Csikszentmihalyi and Csikszentmihalyi 1988; Eisenberger et al. , 2005). Medium levels of competence give people confident in their abilities to complete and perform well in the activity. This can prepare them well to approach the activity (Wenden, 1995), but also become fully absorbed and enjoy the engagement (Csikszentmihalyi and Csikszentmihalyi, 1988; Csikszentmihalyi and LeFevre, 
1989; Fritz and Avsec, 2007). Such conditions are not likely to be found among project leaders with either very low or very high competence in leading projects. We thus hypothesize that project leaders with intermediate levels of competence will have the highest obsessive passion for the projects they manage. Thus:

Hypothesis 1. There is an inverted U-shaped relationship between project leaders’ level of competence and their experience of obsessive passion for the project.

We believe the same logic underlies the relationship between the teams’ competence and the project leaders' obsessive passion. This is because people adjust their feelings, thoughts, and behavior in relation to the competence of others (Brewer and Weber, 1994; Burleson et al., 2005; Rink and Ellemers, 2007; Scott, 1997). When project leaders lack competent team members that are able or willing to contribute to the productivity of an important team task, they may feel the need to compensate and engage themselves, because the teams' overall input appears inadequate (Crawford, 2005; Gillard and Price, 2005; Karau and Williams, 1997; Plaks and Higgins, 2000; Williams and Karau, 1991). This situation increases anxiety and fear, worry, or unease that the efforts will not succeed because of the added role pressure on the project leader (Csikszentmihalyi and Csikszentmihalyi, 1988; Mathwick and Rigdon, 2004; Plaks and Higgins, 2000). When exposed to such pressures, it is likely that the project leader will not develop the intense feeling of joy associated with obsessive passion for the project.

In contrast, when the team surrounding the project leader is highly competent, this may also restrict the project leaders’ obsessive passion. Whereas a highly competent team helps the project leader identify with the team to a greater extent (Redersdorff and Martinot, 2009), this may, however, also make leading the project less challenging (see e.g., Harkins and Petty, 1982; 
Latané et al., 1979; Plaks and Higgins, 2000). The presence of collective competence signals to the project leader that his or her effort is not as important or necessary because the team can perform rather well without the project leader interfering (Harkins and Petty, 1982; Latané et al., 1979). The project leader may thus be more inclined to conserve his or her efforts (Harkins and Petty, 1982; Karau and Williams, 1993, 1997; Latané et al., 1979; Plaks and Higgins, 2000; Williams and Karau, 1991). When the project leader is surrounded by a highly competent team, it is likely the leaders will feel bored, less enthusiastic, and less excited, similar to the situation when they are highly competent themselves (cf. Csikszentmihalyi, 1999). We thus expect that project leaders surrounded by a team that is intermediately competent will experience the greatest obsessive passion for their projects. This leads us to the next hypothesis:

Hypothesis 2. There is an inverted U-shaped relationship between project teams' level of competence and the project leaders' experience of obsessive passion for the project.

\subsubsection{Obsessive passion and project goals}

We suspect that the benefits of passion for the competence-goal attainment association can be found in the literature claiming that motivational mechanisms are important for this relationship (Baum et al., 2001; Ferla et al., 2010). Interestingly, this literature emphasizes the significant benefits of high motivation—including obsessive passion—when individuals face challenging goals. The level of goal challenge is characterized by how difficult or complex the task is, based on task content, its intensity, or the probability of succeeding (Fried and Slowik, 2004; Locke, 1996; Locke et al., 1981; Locke and Latham, 2002). When striving to attain such goals, individuals need to work hard, persist, and actively focus and leverage their competence into significant task effort. Without such effort and individual investments of competence, it is likely that the proficiency or level of performance required to reach those goals will be difficult 
to attain (Locke, 1996; Locke et al., 1981). Attaining such goals demands significant focus and attention. Goal theory predicts that the direction of this required focus is governed by motivational mechanisms (Bryan and Locke, 1967; Hollenbeck et al., 1989). As such, based on goal theory arguments (e.g., Latham and Locke, 1975) and the notion that obsessive passion is a strong motivating mechanism, we expect that the strength of goal challenge effects on attaining project goals will be positively moderated by the project leader's level of obsessive passion. This is consistent with the goal literature's acknowledged need for motivational mechanisms (Latham and Locke, 1975; Locke 1966; Locke and Bryan, 1966, 1967; Locke and Latham, 2002, 2006; Locke et al., 1981). Next, we argue why obsessive passion is likely to positively moderate the relationship between goal challenge and goal attainment.

Previous research has shown that how well an individual performs challenging goals depends on goal commitment, which is defined as the individual's determination to attempt to reach a goal and the persistence in which that goal is pursued over time (Donovan and Radosevich, 1998; Hollenbeck et al., 1989; Klein et al., 1999; Locke, et al., 1981; Locke and Latham, 2002). This is a fundamental reason why obsessive passion strengthens the relationship between how challenging the goal is and goal attainment. The sense of excitement an individual with high passion derives from engaging in an activity becomes uncontrollable and breeds a strong, irresistible impulse to engage in the activity (Vallerand et al., 2007). It is well recognized that obsessive interest in the activity may lead to better performance because of the engagement it creates (Locke and Bryan 1966, 1967; Locke and Latham, 2002; Van Yperen, 2003). Previous research has suggested that obsessive passion prevail in situations in which goals are associated with high demands (e.g., Amiot et al., 2006). In addition, this is consistent with passion research, which has demonstrated the positive association between obsessive passion and deliberate practice (Vallerand et al., 2007, 2008). Deliberate practice, an effortful activity motivated by 
proving performance, is a key activity in acquiring expertise (Ericsson et al., 1993; Ericsson and Charness, 1994; Krampe and Ericsson, 1996). Furthermore, challenging goals can be attained with deliberate practice when individuals receive immediate, informative feedback showing progress in relation to the established goals. This implies that individuals spend extensive time working on difficult and challenging goals in order to optimize attaining those goals. Consequently, we expect that project leaders with high obsessive passion may more effectively attain challenging goals. This results in our third hypothesis:

Hypothesis 3. Project leaders' obsessive passion and the level of goal challenge in the project interact in ways such that project leaders with high obsessive passion in projects with high goal challenges will reach higher goal attainment than project leaders with high obsessive passion working in projects with low goal challenges.

The reasoning for Hypotheses 1 to 3 implies that obsessive passion mediates the influence of both project leaders' competence and team members’ competence on attaining goals. Put differently, if competence influences obsessive passion and obsessive passion is connected to attaining goals, competence and goal attainment are linked indirectly by obsessive passion. Notably, the association between obsessive passion and goal attainment, however, is contingent on a project's goal challenges. We thus acknowledge complicating circumstances for the mediating role of obsessive passion. The overall framework being established to test is a “moderated mediation model” (Baron and Kenny, 1986), where the influence of the mediator (obsessive passion) on the dependent variable (goal attainment) is moderated by another factor (goal challenge). To prove the validity of the framework, it is thus necessary to test for moderated mediation. 


\section{Method}

\subsection{Sample and data collection}

The sample used to test the present study’s hypotheses included 134 individuals leading projects working toward regional development in Sweden. The projects were all funded by the European Union's (EU) structural funds, which have as their main objective to create new jobs and new firms in the regions in which the projects are carried out. This sample allowed us to use multiple data sources and a longitudinal time dimension to test the relationships presented. Because this study accessed multiple data sources, the sample also limited the influence of common method bias.

From the EU program coordinators, we obtained a list of the 324 projects the EU structural funds supported in the northern part of Sweden from 2007 onward. We emailed a questionnaire to the project leader for each of these projects $(N=324)$. We included a cover letter in which the participants were informed that the study focused on their project's progress and conditions and that the questions would address both the project and their perspective as project leaders. Moreover, it was made clear that all answers would be confidential. In total, 134 completed questionnaires were returned, reflecting a response rate of $41.4 \%$. In addition to the survey questions related to passion, we used secondary data to evaluate the effects on goal attainment.

\subsection{Measures and measurement quality}

For several of the variables, the survey included a series of items to be rated on 5-point Likert scales anchored by $1=$ not at all and $5=$ to a great extent. The two competence variables were captured by asking the project leader to rate his or her experience and team members’ experience in the following areas: working on (a) projects of similar size, (b) projects with similar content, and (c) projects in other domains. For the scale assessing the project leaders' 
competence, the Cronbach's $\alpha$ was 0.73 , and for scale assessing the teams' competence the Cronbach's $\alpha$ was 0.87 . To measure obsessive passion, we used an abridged version of Vallerand et al.'s (2003) Passion Scale. A sample item is: ‘The urge is so strong I can’t help myself from engaging in leading this project' (Cronbach's $\alpha .81)$.

Because the EU program's intent is to result in regional development, creating new jobs and new firms in the region aligns with the goal formation process in these projects. To assess goal challenge, we gathered data from the project application to the EU, taking the reported sum of the number of new jobs and firms that the project aimed to establish. Goal attainment was then assessed by summing the new jobs and new firms that had been attained.

We also included four control variables. We controlled for harmonious passion, and similar to our measure of obsessive passion we used a shortened scale from Vallerand et al. (2003). A sample item is: 'Leading this project allows me to live memorable experiences' (Cronbach's $\alpha$.78). The EU structural funds run in program periods of six years, and project applications are submitted and approved continuously during this period. We controlled, therefore, for how the project approval time could influence the relationships in the study. The projects were categorized into eight different time periods, where 8 indicated projects in the sample approved earliest (i.e., operating for the longest time), and 1 indicated the projects in the sample approved latest (i.e., operating for the shortest time). In the analyses, we also controlled for the Swedish region in which the project operated, the number of people on the project board, and the number of industry partners connected to the project.

We engaged multiple tests of measurement reliability and validity. Following Gerbing and Hamilton (1996) the quality of the multi-item measurements was tested using SPSS and the exploratory factor analysis (EFA) option with VARIMAX rotation to detect poorly performing items in each measurement. The EFA revealed the expected factor structures without cross 
loadings of significance (cross loadings $<.30$ ). The factor loadings are displayed in Table 1 . Notable is that both the scree plot and an eigenvalue of 1.0 yielded the factors reported in Table 1. Moreover, the individual loadings for each factor were well above the recommended levels of .70 (Bagozzi and Yi, 1988). Next, using AMOS 17.0 and confirmatory factor analysis (CFA), we

further noticed the individual measurements fitted the data satisfactory $\left(\chi^{2}=135.25, \mathrm{df}=89(p<\right.$ .05 ), $\mathrm{RMSEA}=.063, \mathrm{GFI}=.90 \mathrm{CFI}=.94$, and $\mathrm{IFI}=.94)$. These analyses provide convincing evidence of reliability and discriminant validity of the measurements used.

\section{--- INSERT TABLE 1 ABOUT HERE---}

\subsection{Analyses}

The hypotheses and the underlying claims of moderated mediation were tested using hierarchical ordinary-least-squares (OLS) and the recommendations by Baron and Kenny (1986), which suggested using a series of hierarchical regression equations to evaluate such frameworks. We present the equations in a two-step procedure:

STEP 1. The objective of Step 1 was to confirm the influences of project leader competence and team competence on obsessive passion. We posited inverted U-shape relationships. Three models were used to test these influences.

STEP 1, MODEL 1: A baseline model with control variables:

OBSESSIVE PASSION $=\beta_{0}+\beta_{1}$ HARMONIOUS PASSION $+\beta_{2}$ APPROVAL $+\beta_{3}$ REGION $+\beta_{4}$ PROJECT BOARD SIZE $+\beta_{5}$ INDUSTRY PARTNERS $+\varepsilon$,

STEP 1, MODEL 2: A model for evaluating possible linear effects of competencies: OBSESSIVE PASSION $=\beta_{0}+\beta_{1}$ HARMONIOUS PASSION $+\beta_{2}$ APPROVAL $+\beta_{3}$ REGION $+\beta_{4}$ PROJECT BOARD SIZE $+\beta_{5}$ INDUSTRY PARTNERS $+\beta_{6}$ PROJECT LEADERS' COMPETENCE $+\beta_{7}$ TEAM MEMBERS' COMPETENCE $+\varepsilon$, 
STEP 1 MODEL 3: A model for evaluating hypothesized nonlinear effects of competencies: OBSESSIVE PASSION $=\beta_{0}+\beta_{1}$ HARMONIOUS PASSION $+\beta_{2}$ APPROVAL $+\beta_{3}$ REGION $+\beta_{4}$ PROJECT BOARD SIZE $+\beta_{5}$ INDUSTRY PARTNERS $+\beta_{6}$ PROJECT LEADERS' COMPETENCE $+\beta_{7}$ TEAM MEMBERS' COMPETENCE $+\beta_{8}$ PROJECT LEADERS' COMPETENCE SQUARED $+\beta_{9}$ TEAM MEMBERS’ COMPETENCE SQUARED $+\varepsilon$,

STEP 2. The objective of Step 2 was to establish the interaction of obsessive passion and goal challenge on the dependent variable, goal attainment, while controlling for influences of project leader competence and team competence. Direct effects of competences should be eliminated, or at least reduced, in the presence of adding the interaction in the equation. Two models were used to test these influences.

STEP 2, MODEL 1: A control model:

GOAL ATTAINMENT $=\beta_{0}+\beta_{1}$ HARMONIOUS PASSION $+\beta_{2}$ APPROVAL $+\beta_{3}$ REGION $+\beta_{4}$ PROJECT BOARD SIZE $+\beta_{5}$ INDUSTRY PARTNERS $+\beta_{6}$ PROJECT LEADERS' COMPETENCE $+\beta_{7}$ TEAM MEMBERS' COMPETENCE $+\beta_{8}$ PROJECT LEADERS' COMPETENCE SQUARED $+\beta_{9}$ TEAM MEMBERS' COMPETENCE SQUARED $+\varepsilon$, (4)

STEP 2, MODEL 2: An interaction model:

GOAL ATTAINMENT $=\beta_{0}+\beta_{1}$ HARMONIOUS PASSION $+\beta_{2}$ APPROVAL $+\beta_{3}$ REGION $+\beta_{4}$ PROJECT BOARD SIZE $+\beta_{5}$ INDUSTRY PARTNERS $+\beta_{6}$ PROJECT LEADERS' COMPETENCE $+\beta_{7}$ TEAM MEMBERS' COMPETENCE $+\beta_{8}$ PROJECT LEADERS' COMPETENCE SQUARED $+\beta_{9}$ TEAM MEMBERS' COMPETENCE SQUARED $+\beta_{10}$ GOAL CHALLENGE $+\beta_{11}$ OBSESSIVE PASSION $+\beta_{12}$ (GOAL CHALLENGE X OBSESSIVE PASSION) $+\varepsilon$,

\section{Results}


Table 2 presents the descriptive statistics and the correlation matrix for the studied variables. The correlation matrix suggests no issues of multicollinearity, as low correlations exist among the independent variables. In the present study's analysis, a check for multicollinearity using variance inflation factor analysis with the scores calculated for each variable in the models tested, was below 2, which is well below cut-off values (Ryan, 1997). This suggests that the results do not suffer from multicollinearity. Nevertheless, to mitigate any issues of multicollinearity, we standardized all variables before entering any analyses (Aiken and West, 1991).

--- INSERT TABLE 2 ABOUT HERE---

Table 3 reports the OLS regression models used to evaluate the framework and the hypotheses. Step 1 relates to Hypothesis 1 and 2, whereas Step 2 relates to Hypothesis 3. To reduce complexity, we present in Table 3 only the information necessary to test and evaluate the accuracy of the hypothesized framework.

Step 1, Model 1 reports the influence of the control variables on obsessive passion. Model 1 is a baseline model to test Hypothesis 1 and 2, which suggest an inverted U-shaped relationship between project leaders' competence and obsessive passion for the project (H1), and an inverted U-shaped relationship between project teams' level of competence and the project leaders' experience of obsessive passion for the project (H2). Step 1, Model 2 includes project leaders' competence and team members' competence in addition to the control variables to test possible linear effects from the two types of competence. Step 1, Model 3 introduces the squared effects from the two competence variables to evaluate the presence of inverted U-shaped relationships on the project leaders' obsessive passion while controlling for effects from the control variables and any potential linear direct influence of the competence variables. 
The baseline model in Step 1 shows that the controls of harmonious passion $(\beta=.27, p<$ $.01)$, the project approval $(\beta=.17, p<.05)$, and project board size $(\beta=.18, p<.05)$ significantly influence project leaders' obsessive passion for the project. The results in Step 1, Model 2 and 3 do not support Hypothesis 1 because the influence of project leaders' competence on obsessive passion is represented better by a linear relationship $(\beta=.21, p<.05)$ than a nonlinear relationship ( $\beta=.12, p=\mathrm{ns}$ ). This means that the "boredom effect," which suggests boredom among highly competent project leaders that would mitigate the individual feeling high levels of obsessive passion, is not supported by our data. Step 1, Model 3, however, supports the in Hypothesis 2 suggested nonlinear relationship between teams' competence and the project leaders' obsessive passion $(\beta=-.21, p<.05)$. Comparing the variance explained by Step 1 , Models 2 and 3 add evidence that including the squared term in Model 3 increases the $R^{2}$ term, suggesting a better model $\left(\Delta R^{2}=.04\right)$. We plotted this relationship in Figure 2. This pattern also suggests that a maximum level of obsessive passion is obtained; thereafter, the effect from teams' competence is reduced.

--- INSERT TABLE 3 ABOUT HERE---

--- INSERT FIGURE 2 ABOUT HERE---

Hypothesis 3 posited that the higher the project leader's obsessive passion, the more likely it will be that challenging project goals are attained. As our framework indicates, we posit this moderation to be a key mechanism for understanding the complex relationship between competence in the project and how well project goals are attained. This hypothesis was tested in Step 2, Model 1 by allowing for possible influences from control variables and any linear or nonlinear influences from the two types of perceived experience variables on attaining goals. The 
results report no influence on goal attainment from the controls or any linear or nonlinear direct effects from the project leader's competence or the team's competence. In Step 2, Model 2, the interaction term of obsessive passion and goal challenge is tested, while the effects of the controls, the competence variables, and the direct influence of obsessive passion and goal challenge are controlled. The findings establish, however, that the interaction term between project leaders' obsessive passion and goal challenge is significantly related to attaining goals ( $\beta$ $=.20, p<.05)$. These findings, combined with the absence of direct influences from the competence variables on goal attainment, suggest that the goal challenge and goal attainment relationship is moderated by project leaders’ obsessive passion. Project leaders’ obsessive passion is thus a key construct for understanding the complex relationship between competence and attaining project goals. Figure 3 plots the interaction term between goal challenge and obsessive passion and its influence on goal attainment. It illustrates that when project leaders experience high obsessive passion for the project, the relationship between goal challenge and goal attainment is stronger than when the project leader has low obsessive passion. Overall, the results provide solid support for the claim in Hypothesis 3 that obsessive passion plays an important role in linking the benefits of competence through challenging goals to successful goal attainment.

\section{--- INSERT FIGURE 3 ABOUT HERE---}

In sum, the underlying moderated mediation model is supported significantly by the series of hierarchical regression equations. Obsessive passion is a mediating link of influence of competence on goal attainment. Moreover, because overly competent team members reduce the levels of obsessive passion needed to execute challenging project goals for project leaders, we 
find overall support for our explanation of why overly competent project teams may fail to reach challenging goals.

\section{Discussion}

The purpose of this study was to examine both theoretically and empirically the links among competence, obsessive passion, and project management. With the first hypothesis, we proposed that project leaders with medium levels of competence will have the highest level of obsessive passion for their project. Our findings indicate that the inverted U-shaped relationship between the project leader's competence and his or her experienced obsessive passion was not supported. Instead, the results showed a positive linear relationship between project leaders’ competence and obsessive passion. Our second prediction supports the hypothesis that there is a nonlinear relationship between team members’ competence and project leaders’ obsessive passion. When project teams are very competent, the extreme levels of obsessive passion in project leaders are likely reduced.

This reduced passion level is important in the light of our third finding, which suggested that the hypothesized relationship between goal challenge and goal attainment is positively moderated by the project leader's obsessive passion. Our analyses indicate that at higher levels of goal challenge in the project, goal attainment is higher when the project leaders have higher levels of obsessive passion. Broadly speaking, this finding underscores that the project leaders' obsessive passion as a key mechanism in contexts with high goal challenges and the risk of having overly competent team members in such contexts. When competence levels are extensively high, the strong passion that is needed to attain challenging goals is mitigated among project leaders. This explains why overly competent teams may fail to reach challenging goals, an issue that has been highlighted in previous project management research (e.g., Papke-Shields 
et al., 2010; Sotiriou and Wittmer, 2001). This occurs because the project leaders “relax,” which is not an ideal state when leading large and challenging projects.

Our research has clear implications for practice and theory. When teams are overly competent, the present study indicates that project leaders lose the anxious feeling that drives them to direct team members to attain goals. Therefore, leaders managing R\&D projects, for example, are encouraged to find ways to challenge their teams. By doing so, there will be a greater need for a project leader that guides the team in how to reach goals when there may be a gap between the team's competence and the objectives for which they are aiming. This situation will likely push the project leaders to invest more effort on the project team. In other words, to continually keep the fire burning, project leaders should continually introduce more demanding situations for the project team, even though they may partly doubt that the team's competence is sufficient to reach the goals. This points to that the organization and project leaders alike should consider the importance of their own passion and their team members' competence levels before, during, and after specific tasks are undertaken. Considering that the data showed no direct effect on goal attainment from either the project leaders' competence or the team's competence, this further strengthens indications in prior research that competence is not sufficient for attaining goals. It also adds to insights that passion is one example of a motivational dimension that is needed. We believe, therefore, that much can be learned by reflecting on this study's results. Although previous research has highlighted the negative sides associated with obsessive passion (and thus something that management should manage with extra care), this study advances the notion that it is also important to be aware of the benefits of such passion for work activities when goals are challenging.

By examining the relationships between competence and obsessive passion and between goal challenge and goal attainment, our results contribute to discussions about competence, 
passion research, and goal-setting theory in several ways. First, our study extends previous research on the relationship between competence and goal attainment by testing and supporting the role of obsessive passion. As hypothesized, and consistent with conceptual dialogues and prior discussions (Locke and Latham, 2002, 2006), a motivational dimension must be present for competence to transform into performance. We have demonstrated that obsessive passion is one example of such a motivational dimension. Second, our study contributes to passion research by highlighting the positive role and importance of obsessive passion in certain situations. The present study is one of the first to suggest that obsessive passion can lead to positive consequences, which is something that previous research has overlooked (e.g., Vallerand, et al., 2007, 2008). Third, research on attaining goals has shown that high levels of commitment, persistence, and effort lead to higher levels of attaining goals when those goals are challenging (Hollenbeck et al., 1989; Klein et al., 1999; Locke and Latham, 2002). The present study thus extends the understanding of goal attainment by suggesting that individuals, in this case project leaders, with high obsessive passion are able to achieve goals that are more challenging. This shows that passion is an important factor for individuals' coping with and attaining challenging goals.

The present study, however, is not without limitations. First, it is limited to our reliance on a sample of project leaders of large EU projects. Consequently, we are less certain about our ability to generalize our results to other populations. Second, although we have shown the moderating effect of obsessive passion on goal challenge and goal attainment, there are other possible measures of goal attainment that could quite possibly be used to obtain a broader picture. Finally, each team leader in our study provided information on the competence of a reasonably large number of team members. We thus encourage future research to refine or find alternatives to the measure of the team competence. 
In conclusion, our findings indicate that the project leader's obsessive passion is an important factor for directing competent team members to meet challenging project goals. We hope that this study's results spur additional research encompassing how individuals' obsessive passion, enjoyment, and strong emotions are important and needed in combination with competence to reach positive outcomes. Such research could further the field's understanding of why certain projects fail, but yet certain others succeed in attaining their goals.

\section{References}

Aiken, L.S., West, S.G., 1991. Multiple regression: Testing and interpreting interactions. Newbury Park, CA: Sage.

Amiot, C.E., Vallerand, R.J., Blanchard, C.M., 2006. Passion and psychological adjustment: A test of the person-environment fit hypothesis. Personality and Social Psychology Bulletin, 32 (2), 220-229.

Aubry, M. Lièvre, P., 2010. Ambidexterity as a competence of project leaders: a case study from two polar expeditions. Project Management Journal, 41 (3), 32-44.

Baccarini, D, 1996. The concept of project complexity- a review. International Journal of Project Management,14 (4), 201-204.

Bagozzi, R.P., Yi, Y., 1988. On the evaluation of structural equation models. Journal of the Academy of Marketing Science, 16 (1), 74-94.

Baron, R.A., Kenny, D.A., 1986. The moderator-mediator variable distinction in social psychological research: Conceptual, strategic, and statistical considerations. Journal of Personality and Social Psychology, 51 (6), 1173-1182.

Baum, J.R., Locke, E.A., Smith, K.G., 2001. A multidimensional model of venture growth. Academy of Management Journal, 44 (2), 292-303. 
Best, R.G., Stapleton, L.M., Downey, R.G., 2005. Core self-evaluations and job burnout: The test of alternative models. Journal of Occupational Health Psychology, 10 (4), 441-451.

Bonneville-Roussy, A., Lavigne, G.L., Vallerand, R.J., 2011. When passion leads to excellence: The case of musicians. Psychology of Music, 39 (1), 123-138.

Boyatzis, R.E. 1982. The Competent manager: A model for effective performance. New York: John Wiley and Sons, Inc.

Brewer, M.B. Weber, J.W., 1994. Self-evaluation effects of interpersonal versus intergroup social comparison. Journal of Personality and Social Psychology, 66 (2), 268-275.

Bryan, J.F., Locke, E.A., 1967. Goal setting as a means of increasing motivation. Journal of Applied Psychology, 53 (3), 274-277.

Burleson, K., Leach, C.W., Harrington, D.M., 2005. Upward social comparison and self-concept: Inspiration and inferiority among art students in an advanced programme. British Journal of Social Psychology, 44 (1), 109-123.

Caldwell, L.L., Smith, E.A., Weissinger, E., 1992. Development of a leisure experience battery for adolescents: parsimony, stability, and validity. Journal of Leisure Research, 24 (4), 361-376.

Coatsworth, J.D., Conroy, D.E., 2009. The effects of autonomy-supportive coaching, need satisfaction, and self-perceptions on initiative and identity in youth swimmers. Developmental Psychology, 45 (2), 320-328.

Crawford, L., 2005. Senior management perceptions of project management competence. International Journal of Project Management, 23 (1), 7-16.

Csikszentmihalyi, M., 1999. If we are so rich, why aren’t we happy? American Psychologist, 54 (10), 821-827. 
Csikszentmihalyi, M., Csikszentmihalyi, I.S. (Eds.), 1988. Optimal experience: Psychological studies of flow in consciousness. New York: Cambridge University Press.

Csikszentmihalyi, M., LeFevre, J., 1989. Optimal experience in work and leisure. Journal of Personality and Social Psychology, 56 (5), 815-822.

de Korwin, A., Shipley, M., Kleyle, R., 2002. Utilizing fuzzy compatibility of skill sets for team selection in multi-phase projects. Journal of Engineering and Technology Management, 19 (3-4), 307-319.

Deci, E.L., Ryan, R.M., 2000. The “what” and "why” of goal pursuits: Human needs and the selfdetermination of behavior. Psychological Inquiry, 11 (4), 227-268.

Donovan, J.J., Radosevich, D.J., 1998. The moderating role of goal commitment on the goal difficulty-performance relationship: A meta-analytic review and critical reanalysis. Journal of Applied Psychology, 83 (2), 308-315.

Dweck, C.S., 1992. The study of goals in psychology. Psychological Science, 3 (3), 165-167.

Eisenberger, R., Jones, J.R., Stinglhamber, F., Shanock, L., Randall, A. T., 2005. Flow experiences at work: For high need achievers alone? Journal of Organizational Behavior, 26 (7), 755-775.

Forest, J., Mageau, G. A., Sarrazin, C., \& Morin, E. M. 2011. "Work is my passion": The different affective, behavioural, and cognitive consequences of harmonious and obsessive passion toward work. Canadian Journal of Administrative Sciences-Revue Canadienne Des Sciences De L Administration, 28 (1), 17-30

Fried, Y., Slowik, L.H., 2004. Enriching goal-setting theory with time: An integrated approach. Academy of Management Review, 29 (3), 404-422. 
Elliot, A.E., Faler, J., McGregor, H.A., Campbell, W.K., Sedikides, C., Harackiewicz, J.M., 2000. Competence valuation as a strategic intrinsic motivation process. Personality and Social Psychology Bulletin, 26 (7), 780-794.

Ericsson, K.A., Charness, N., 1994. Expert performance: Its structure and acquisition. American Psychologist, 49 (8), 725-747.

Ericsson, K.A., Krampe, R.T., Tesch-Römer, C., 1993. The role of deliberate practice in the acquisition of expert performance. Psychological Review, 100 (3), 363-406.

Ferla, J., Valcke, M., Schuyten, G., 2010. Judgments of self-perceived academic competence and their differential impact on students’ achievement motivation, learning approach, and academic performance. European Journal of Psychology of Education, 25 (4), 519-536.

Fritz, B.S., Avsec, A., 2007. The experience of flow and subjective well-being of music students. Horizons of Psychology 16 (2), 5-17.

Geiwitz, P.J., 1966. Structure of boredom. Journal of Personality and Social Psychology, 3 (5), 592-600.

Gerbing, D.W., Hamilton, J.G., 1996. Viability of exploratory factor analysis as a precursor to confirmatory factor analysis. Structural Equation Modeling, 3 (1), 62-72.

Gillard, S., Price, J., 2005. The competence of effective project managers: a conceptual analysis. International Journal of Management, 22 (1), 48-53.

Haon, C., Gotteland, D., Fornerino, M., 2009. Familiarity and competence diversity in new product development teams: Effects on new product performance. Marketing Letters, 20 (1), 75-89.

Harkins, S.G., Petty, R.E., 1982. Effects of task difficulty and task uniqueness on social loafing. Journal of Personality and Social Psychology, 43 (6), 1214 -1229. 
Hollenbeck, J., Williams, C., Klein, H., 1989. An empirical examination of the antecedents of commitment to difficult goals. Journal of Applied Psychology, 74 (1), 18-23.

Jha, K.N. Iyer, K.C., 2007. Commitment, coordination, competence and the iron triangle. International Journal of Project Management, 25 (5), 527-540.

Karau, S.J., Williams, K.D., 1993. Social loafing: A meta-analytic review and theoretical integration. Journal of Personality and Social Psychology, 65 (4), 681-706.

Karau, S.J.,Williams, K.D., 1997. The effects of group cohesiveness on social loafing and social compensation. Group Dynamics: Theory, Research, and Practice, 1 (2), 156-168.

Kaslow, N.J., 2004. Competencies in professional psychology. American Psychologist, 59 (8), 774-781.

Kaslow, N.J., Rubin, N.J., Forrest, L., Elman, N.S., Van Horne, B.A., Jacobs, S.C., Huprich, S.K., Benton, S.A., Pantesco, V.F., Dollinger, S.J., Grus, C.L., Behnke, S.H., Shen Miller, D.S., Shealy, C.N., Mintz, L.B., Schwartz-Matte, R., Sickle, K.V., Thorn, B.E., 2007. Recognizing, assessing, and intervening with problems of professional competence. Professional Psychology: Research and Practice, 38 (5), 479-492.

Kauffeld, S., 2006. Self-directed work groups and team competence. Journal of Occupational and Organizational Psychology, 79 (1), 1-21.

Klein, H., Wesson, M., Hollenbeck, J., Alge, B., 1999. Goal commitment and the goal-setting process: Conceptual clarification and empirical synthesis. Journal of Applied Psychology, 84 (6), 885-896.

Kor, Y.Y., 2003. Experience-based top management team competence and sustained growth. Organization Science, 14 (6), 707-719. 
Krampe, R.T., Ericsson, K.A., 1996. Maintaining excellence: Deliberate practice and elite performance in young and older pianists. Journal of Experimental Psychology: General, 125 (4) 331-359.

Lampel, J., 2001. The core competencies of effective project execution: the challenge of diversity. International Journal of Project Management, 19 (8), 471-483.

Latané, B., Williams, K., Harkins, S., 1979. Many hands make light the work: The causes and consequences of social loafing. Journal of Personality and Social Psychology, 37 (6), 822832.

Latham, G.P., Locke, E.A., 1975. Increasing productivity and decreasing time limits: A field replication of Parkinson’s law. Journal of Applied Psychology, 60 (4), 524-526.

Latham, G.P., Locke, E.A., 2006. Enhancing the benefits and overcoming the pitfalls of goal setting. Organizational Dynamics, 35 (4), 332-340.

Locke, E.A., 1966. The relationship of intentions to level of performance. Journal of Applied Psychology, 50 (1), 60-66.

Locke, E.A., 1996. Motivation through conscious goal setting. Applied \& Preventive Psychology, 5 (2), 117-124.

Locke, E.A., Bryan, J.F., 1966. Cognitive aspects of psychomotor performance: The effects of performance goals on level of performance. Journal of Applied Psychology, 50 (4), 286291.

Locke, E.A., Bryan, J.F., 1967. Performance goals as determinants of level of performance and boredom. Journal of Applied Psychology, 51 (2), 120-130.

Locke, E.A., Latham, G.P., 2002. Building a practically useful theory of goal setting and task motivation: A 35-year odyssey. American Psychologist, 57 (9), 705-717. 
Locke, E.A., Latham, G.P., 2006. New directions in goal setting theory. Current Direction in Psychological Science, 15 (5), 265-268.

Locke, E.A., Shaw, K.N., Saari, L.M., Latham, G.P., 1981. Goal setting and task performance: 1969-1980. Psychological Bulletin, 90 (1), 125-152.

Maslach, C., Schaufeli, W.B., Leiter, M.P., 2001. Job burnout. Annual Review of Psychology, 52 (1), 397-422.

Mathwick, C., Rigdon, E., 2004. Play, flow, and the online search experience. Journal of Consumer Research, 31 (2), 324-332.

McComb, S.A., Green, S.G., Compton, W.D., 2007. Team flexibility's relationship to staffing and performance in complex projects: An empirical analysis. Journal of Engineering and Technology Management, 24 (4), 293-313.

Melkonian, T., Picq, T., 2010. Opening the "black box" of collective competence in extreme projects: lessons from the french special forces. Project Management Journal, 41 (3), 7990.

Mikulas, W.L., Vodanovich, S.J., 1993. The essence of boredom. The Psychological Record, 43 (1), 3-12.

Moores, T.T., Chang J.C., 2009. Self-efficacy, overconfidence, and the negative effect on subsequent performance: A field study. Information and Management, 46 (2), 69-76.

Müller, R., Turner, R., 2010. Leadership competency profiles of successful project managers. International Journal of Project Management, 28 (5), 437-448.

Nakamura, J., Csikszentmihalyi, M., 2002. The concept of flow. In C.R. Snyder S.J. Lopez (Eds.), Handbook of Positive Psychology (89-105). Oxford: University Press.

Österlund, J., 1997. Competence management by informatics in R\&D: The corporate level. IEEE Transactions on Engineering Management, 44 (2), 135-145. 
Papke-Shields, K.S., Beise, C., Quan, J., 2010. Do project managers practice what they preach, and does it matter to project success? International Journal of Project Management, 28 (7), 650-662.

Partington, D., Pellegrinelli, S., Young, M., 2005. Attributes and levels of programme management competence: An interpretive study. International Journal of Project Management, 23 (2), 87-95.

Payne, B.R., Jackson, J.J., Noh, S.R., Stine-Marrow, E.A.L., 2011. In the zone: Flow state and cognition in older adults. Psychology and Aging, 26 (3), 738-743.

Peterson, T.M., 2007. Motivation: How to increase project team performance. Project Management Journal, 38 (4), 60-69.

Philippe, F.L., Vallerand, R.J., Houlfort, N., Lavigne, G.L., Donahue, E.G., 2010. Passion for an activity and quality of interpersonal relationships: The mediating role of emotions. Journal of Personality and Social Psychology, 98 (6), 917-932.

Plaks, J.E., Higgins, E.T., 2000. Pragmatic use of stereotyping in teamwork: Social loafing and compensation as a function of inferred partner-situation fit. Journal of Personality and Social Psychology, 79 (6), 962-974.

Redersdorff, S., Martinot, D., 2009. Being outperformed in an intergroup context: The relationship between group status and self-protective strategies. British Journal of Social Psychology, 48 (2), 275-294.

Renn, R.W., Fedor, D.B., 2001. Development and field test of a feedback seeking, self-efficacy, and goal setting model of work performance. Journal of Management, 27 (5), 563-583.

Rink, F., Ellemers, N., 2007. Defining the common feature: Task-related differences as the basis for dyadic identity. British Journal of Social Psychology, 46 (3), 499-515. 
Rodolfa, E., Bent, R., Eisman, E., Nelson, P., Rehm, L., Ritchie, P., 2005. A cube model for competency development: Implications for psychology educators and regulators. Professional Psychology: Research and Practice, 36 (4), 347-354.

Ryan, T.Y., 1997. Modern regression analysis. New York: John Wiley \& Sons.

Sansone, C., 1986. A question of competence: The effects of competence and task feedback on intrinsic interest. Journal of Personality and Social Psychology, 51 (5), 918-931.

Scott, S.G., 1997. Social identification effects in product and process development teams. Journal of Engineering and Technology Management, 14 (2), 97-127.

Shernoff, D.J., Csikszentmihalyi, M., Schneider, B., Shernoff, E.S., 2003. Student engagement in high school classrooms from the perspective of flow theory. School Psychology Quarterly, 18 (2), 158-176.

Spencer, L., Spencer. S., 1993. Competence at Work: Models for superior performance. New York: John Wiley and Sons Inc.

Song, Y.I., Lee, D.H., Lee, Y.G., Chung, Y.C., 2007. Managing uncertainty and ambiguity in frontier R\&D projects: A Korean case study. Journal of Engineering and Technology Management 24 (3), 231-250.

Sotiriou, D., Wittmer, D., 2001. Influence methods of project managers: Perceptions of team members and project managers. Project Management Journal, 32 (3), 12-20.

Söderlund J., 2004. Building theories of project management: Past research, questions for the future. International Journal of Project Management, 22 (3), 183-91.

Stenseng, F., Rise, J., Kraft, P., 2011. The dark side of leisure: Obsessive passion and its covariates and outcomes. Leisure Studies, 30 (1), 49-62. 
Vallerand, R.J., Mageau, G.A., Elliot, A.J., Dumais, A., Demers, M.A., Rousseau, F., 2008.

Passion and performance attainment in sport. Psychology of Sport and Exercise, 9 (3), 373-392.

Vallerand, R.J., Mageau, G.V.A., Ratelle, C., Léonard, M., Blanchard, C.I., Koestner, R., Gagné, M., Marsolais, J., 2003. Les passions de l’ame: On obsessive and harmonious passion. Journal of Personality and Social Psychology, 85 (4), 756-767.

Vallerand, R.J., Reid, G., 1984. On the causal effects of perceived competence on intrinsic motivation: A test of cognitive evaluation theory. Journal of Sport Psychology, 6, (1) 94102.

Vallerand, R.J., Rousseau, F.L., Grouzet, F.M.E., Dumais, A., Grenier, S., Blanchard, C.M., 2006. Passion in sport: A look at determinants and affective experiences. Journal of Sport \& Exercise Psychology, 28 (4), 454-478.

Vallerand R.J., Salvy, S., Mageau, G.A., Elliot, A.J., Denis, P.L., Grouzet, F.M.E., Blanchard, C., 2007. On the role of passion in performance. Journal of Personality, 75 (3), 505-534.

Vallerand, R.J., Paquet, Y., Philippe, F.L., Charest, J., 2010. On the role of passion for work in burnout: A process model. Journal of Personality, 78 (1), 289-312.

Van Yperen, N.W., 2003. Task interest and actual performance: The moderating effects of assigned and adopted purpose goals. Journal of Personality and Social Psychology, 85 (6), 1006-1015.

Vancouver, J.B., Kendall, L.N., 2006. When self-efficacy negatively relates to motivation and performance in a learning context. Journal of Applied Psychology, 91 (5), 1146-1153.

Vancouver, J.B., Thompson, C.M., Tischner, E.C., Putka, D.J., 2002. Two studies examining the negative effect of self-efficacy on performance. Journal of Applied Psychology, 87 (3), 506-516. 
Wenden, A.L., 1995. Learner training in context: A knowledge-based approach. System, 23 (2), 183-194.

Williams, K.D., Karau, S.J., 1991. Social loafing and social compensation: The effects of expectations of co-worker performance. Journal of Personality and Social Psychology, 61 (4), 570-581.

Zhang, S., Tremaine, M., Egan, R., Milewski, A., O’Sullivan, P., Fjermestad, J., 2009. Occurrence and effects of leader delegation in virtual software teams. International Journal of e-Collaboration, 5 (1), 47-68. 


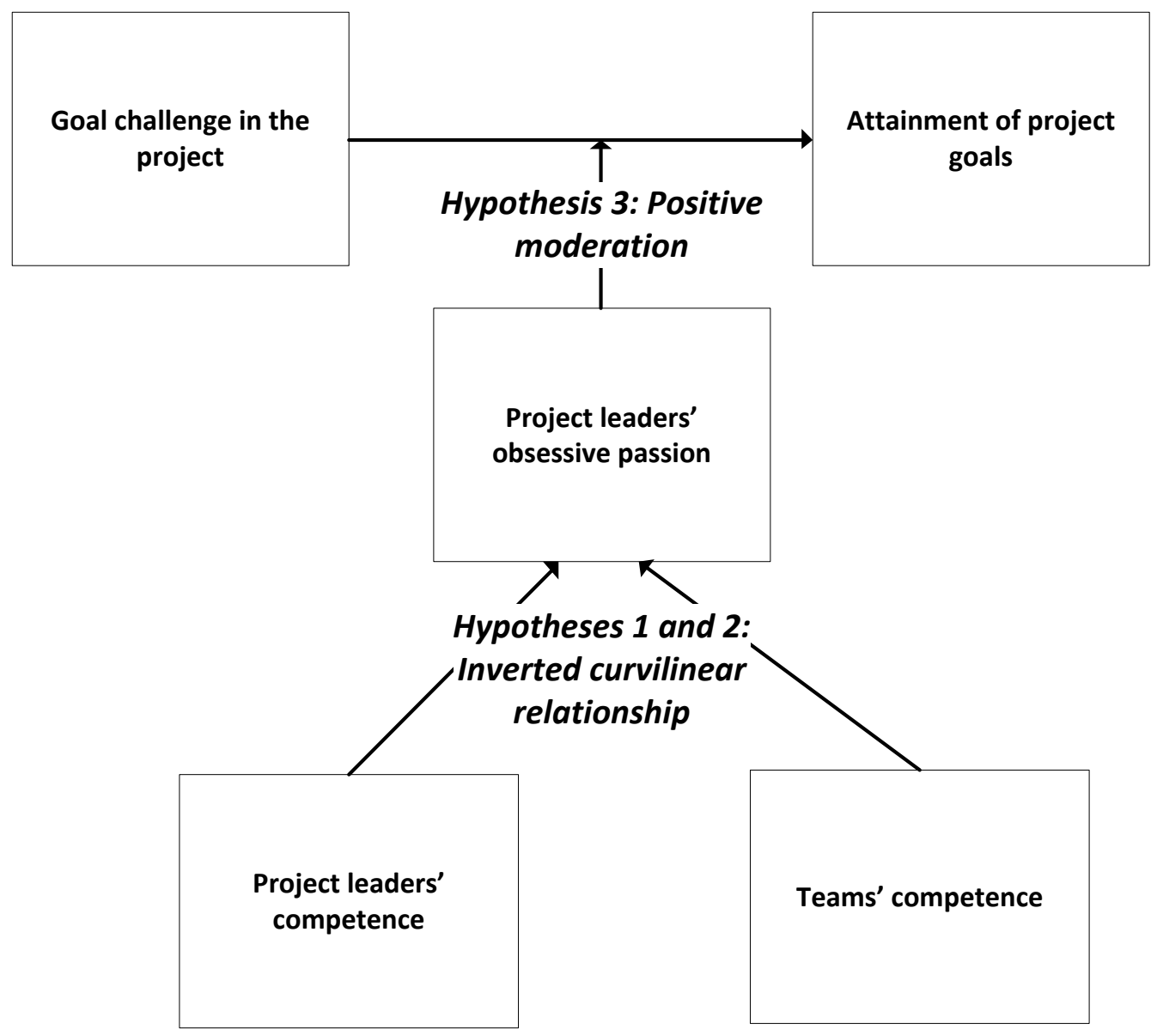

Figure 1. Theoretical framework 


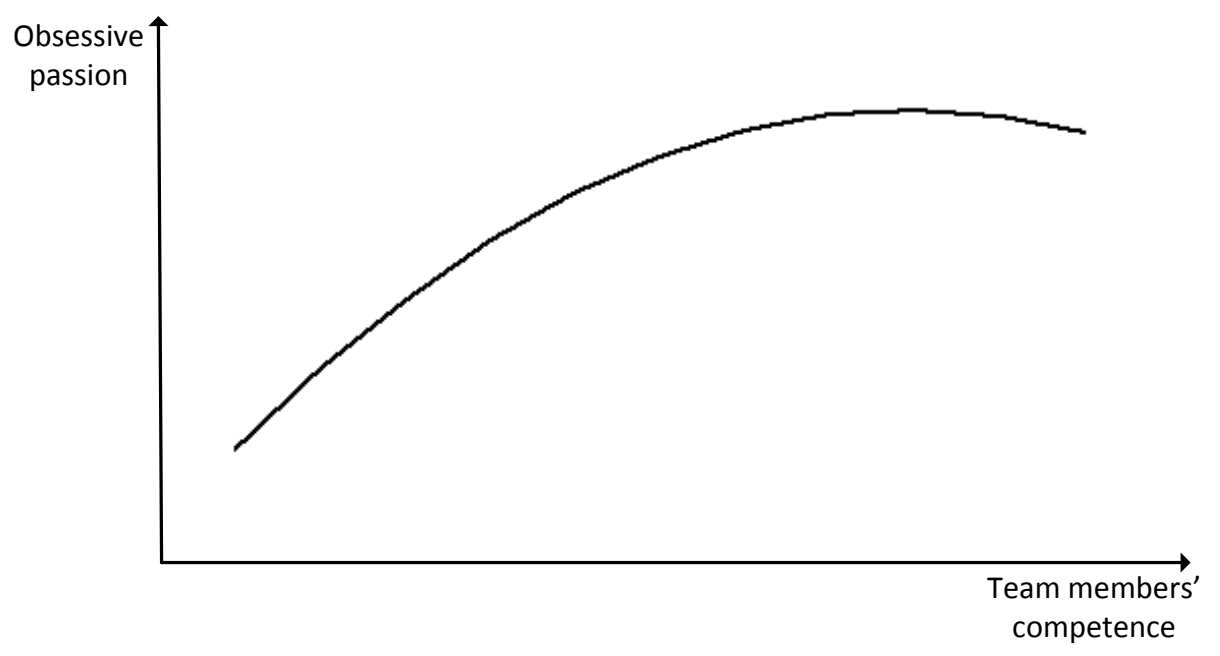

Figure 2. Inverted U-shape relationship between team members’ competence and project leaders’ obsessive passion 


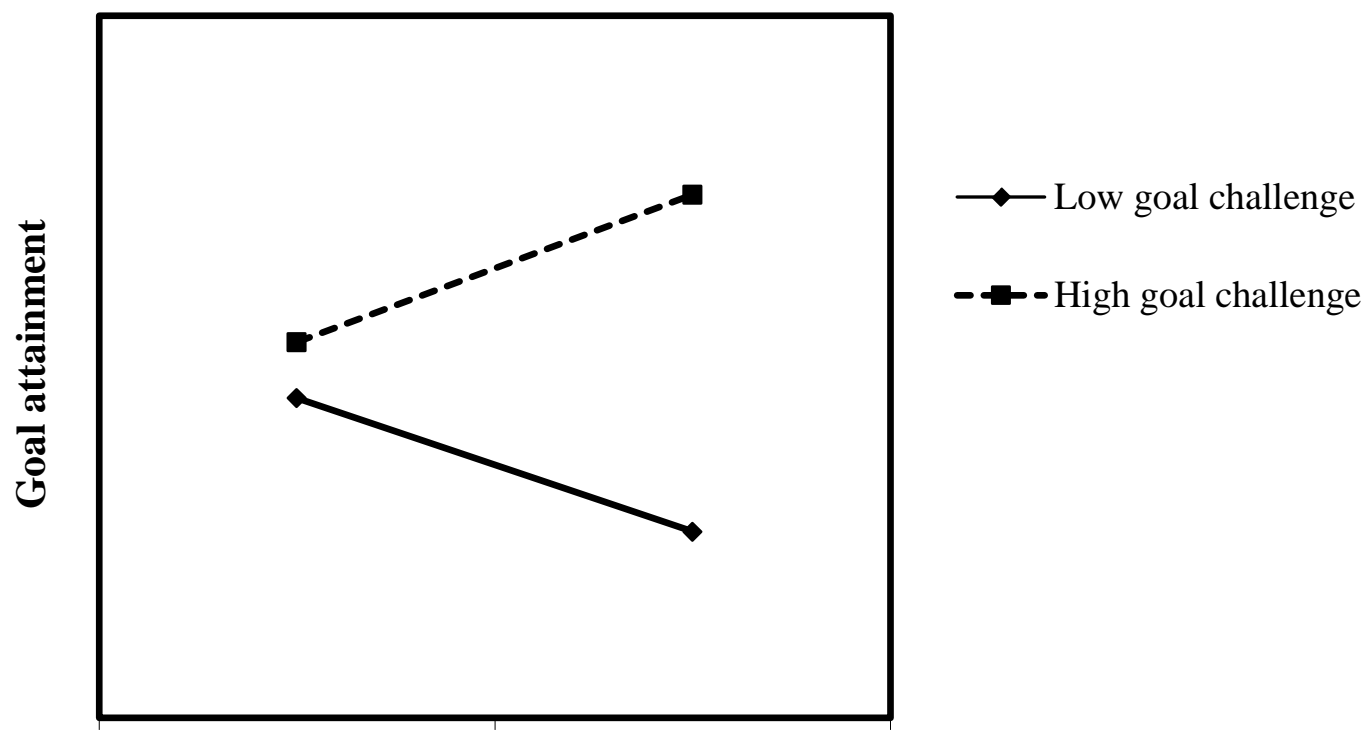

Low obsessive passion High obsessive passion

Figure 3. Interaction effect of project leaders' obsessive passion and the level of project goal challenge on goal attainment 
Table 1. Factor analysis

\begin{tabular}{|c|c|c|c|c|c|c|}
\hline Variables & 1 & 2 & 3 & 4 & 5 & 6 \\
\hline \multicolumn{7}{|l|}{ 1. Project leaders' competence } \\
\hline Own experience from projects of similar size & .85 & & & & & \\
\hline Own experience from projects with similar content & .75 & & & & & \\
\hline Own experience from projects in other domains & .75 & & & & & \\
\hline \multicolumn{7}{|l|}{ 2. Team members' competence } \\
\hline Team members' experience from projects of similar size & & .89 & & & & \\
\hline Team members' experience from projects with similar content & & .88 & & & & \\
\hline Team members' experience from projects in other domains & & .81 & & & & \\
\hline \multicolumn{7}{|l|}{ 3. Harmonious passion } \\
\hline Leading this project allows me to live memorable experiences & & & .79 & & & \\
\hline Leading this project reflects the qualities I like about myself & & & .80 & & & \\
\hline Leading this project allows me to live a variety of experiences & & & .88 & & & \\
\hline \multicolumn{7}{|l|}{ 4. Obsessive passion } \\
\hline I have a tough time controlling my need to engage in this project & & & & .80 & & \\
\hline The urge is so strong I can't help myself from engaging in leading this project & & & & .86 & & \\
\hline I am emotionally dependent on engaging in this project & & & & .81 & & \\
\hline \multicolumn{7}{|l|}{ 5. Goal challenge } \\
\hline The number of new jobs to be created as expressed in the project application & & & & & .98 & \\
\hline The number of new firms to be established as expressed in the project application & & & & & .95 & \\
\hline \multicolumn{7}{|l|}{ 6. Goal attainment } \\
\hline Number of new jobs being created & & & & & & .93 \\
\hline Number of new firms being established & & & & & & .92 \\
\hline
\end{tabular}


Table 2. Correlations between dependent, independent, and control variables

\begin{tabular}{|c|c|c|c|c|c|c|c|c|c|c|c|c|c|}
\hline & Variable & Mean & S.D. & (1) & (2) & (3) & (4) & (5) & (6) & (7) & (8) & (9) & $(10)$ \\
\hline (1) & Project leaders’ competence & 3.99 & .90 & 1.000 & & & & & & & & & \\
\hline (2) & Team members' competence & 3.74 & .94 & $.37 * * *$ & 1.000 & & & & & & & & \\
\hline (3) & Obsessive passion & 2.94 & .86 & $.28 * *$ & $.25 * *$ & 1.000 & & & & & & & \\
\hline (4) & Goal challenge & 130.24 & 475.44 & -.02 & .13 & .18 & 1.000 & & & & & & \\
\hline (5) & Goal attainment & -7.56 & 140.50 & .05 & .05 & .11 & $.31 * * *$ & 1.000 & & & & & \\
\hline (6) & Harmonious passion & 4.23 & .61 & .06 & $.18^{*}$ & $.33^{* * *}$ & .13 & .10 & 1.000 & & & & \\
\hline (7) & Project approval & 4.14 & 1.71 & .01 & -.07 & $.25^{* *}$ & $-.29 * *$ & $.31 * * *$ & $.25^{* *}$ & 1.000 & & & \\
\hline (8) & Region & 0.45 & .50 & $-.30 * * *$ & $-.18^{*}$ & -.12 & -.11 & -.07 & -.15 & .06 & 1.000 & & \\
\hline (9) & Project board size & 4.02 & 3.32 & .07 & .02 & $.17^{*}$ & .17 & .01 & -.06 & -.05 & -.02 & 1.000 & \\
\hline (10) & Industry partners & 25.86 & 31.01 & .04 & .03 & $-.17 *$ & -.06 & -.03 & $-.19 *$ & -.13 & -.01 & .01 & 1.000 \\
\hline
\end{tabular}


Table 3. Results of hierarchical OLS regression

Models and variables

$\beta$

$R^{2}$

$\Delta R^{2}$

STEP I (testing Hypothesis 1 and 2)

Dependent variable: Obsessive passion

Step I; Model 1

Harmonious passion

$.27 * *$

6.02

.19

Project approval

$.17 *$

Region

$-.07$

Project board size

$.18^{*}$

Industry partners

$-.12$

Step I; Model 2 (adds the following variables to Step I; Model 1)

Project leaders' competence

Team members' competence

Step I; Model 3 (adds the following variables to Step I; Model 2)

Project leaders' competence squared

Team members' competence squared

\section{STEP II (testing Hypothesis 3)}

Dependent variable: Goal attainment

Step II; Model 1

Harmonious passion

$-.05$

1.61

Project approval

Region

.01

Project board size

$-.09$

Industry partners

$-.01$

Project leaders' competence

.12

Team members' competence

.07

Project leaders' competence squared

Team members' competence squared

$-.01$

Step II; Model 2 (adds the following variables to Step II; Model 1)

Goal challenge

Obsessive passion $.20 *$

Goal challenge*Obsessive passion

$n=134$; two-tailed tests; ${ }^{*} p<0.05 ;{ }^{* *} p<0.01 ;{ }^{* * *} p<0.001$ 